\title{
Correction to: Quantifying carbon footprint for ecological river restoration
}

\author{
Yiwen Chiu $^{1}$ (D) Yi Yang $^{2} \cdot$ Cody Morse $^{1}$ \\ Published online: 31 May 2021 \\ (c) The Author(s) 2021
}

\section{Correction to: Environment, Development and Sustainability https://doi.org/10.1007/s10668-021-01477-y}

The article "Quantifying carbon footprint for ecological river restoration", written by "Yiwen Chiu, Yi Yang and Cody Morse", was originally published electronically on the publisher's internet portal on 6 May 2021 without open access. With the author(s)' decision to opt for Open Choice, the copyright of the article changed on 17 May 2021 to () The Author(s) [2021] and the article is forthwith distributed under a Creative Commons Attribution.

Open Access This article is licensed under a Creative Commons Attribution 4.0 International License, which permits use, sharing, adaptation, distribution and reproduction in any medium or format, as long as you give appropriate credit to the original author(s) and the source, provide a link to the Creative Commons licence, and indicate if changes were made.

The images or other third party material in this article are included in the article's Creative Commons licence, unless indicated otherwise in a credit line to the material. If material is not included in the article's Creative Commons licence and your intended use is not permitted by statutory regulation or exceeds the permitted use, you will need to obtain permission directly from the copyright holder.

To view a copy of this licence, visit http://creativecommons.org/licenses/by/4.0/.

The original article can be found online at https://doi.org/10.1007/s10668-021-01477-y.

Yiwen Chiu

yichiu@calpoly.edu

Yi Yang

yi.yang@cqu.edu.cn

Cody Morse

codymorse32@gmail.com

1 Department of Natural Resources Management and Environmental Sciences, California Polytechnic State University, 1 Grand Ave, San Luis Obispo, CA 93407, USA

2 Key Laboratory of the Three Gorges Reservoir Region's Eco-Environment, Ministry of Education, Chongqing University, Chongqing 400045, China 
Publisher's Note Springer Nature remains neutral with regard to jurisdictional claims in published maps and institutional affiliations. 